\title{
TECHNICKÉ VZDELÁVANIE V KONTEXTE DIŠTANČNEJ VÝUČBY
}

\author{
HULOVÁ Zlatica, SK - TOKOŠ Peter, SK
}

\begin{abstract}
Resumé
Význam a potreba technického vzdelávania v Slovenskej republike sú nespochybnitel'né. Práve preto je $\mathrm{v}$ súčasnosti nutné zdôrazňovat' potrebu technického vzdelávania mladých l'udí a $\mathrm{v}$ čase uchádzania sa o d'alšie štúdium a vzdelávanie apelovat' na fakt, že každý žiak, študent, má v rukách svoju budúcnost'. Musíme ale konštatovat', že záujem o štúdium technických odborov na stredných odborných školách je nižší, žiaci majú často problémy zvládat' takýto druh štúdia a následne sa úspešne adaptovat' na trhu práce. Technické vzdelávanie je náročné, hlavne pri realizácii dištančnou formou. V tomto článku budeme prezentovat' získané poznatky i skúsenosti z vyučovania technických predmetov počas pandémie nového koronavírusu SARS-CoV-2. Ciel'om tohoto článku je na základe realizácie krátkeho prieskumu formou dotazníka zhodnotit' technické vzdelávanie realizované formou dištančnej výučby, zhodnotit’ pozitívne i negatívne stránky.
\end{abstract}

Kl'účové slová: technické vzdelávanie, dištančná výučba, vyučovacie metódy, moderné koncepcie vyučovacieho procesu, motivácia žiakov, informačno-komunikačné technológie

\section{TECHNICAL EDUCATION IN THE CONTEXT OF DISTANCE LEARNING}

\begin{abstract}
The importance and need for technical education in the Slovak Republic are unquestionable.

That is the reason why it is so important to emphasize the need for technical education of young people, and also at time of applying to further studies and education, to appeal on the fact that every pupil and every student has the future in their hands. We must allege that the interest in studying technical fields at secondary vocational schools is lower, pupils often have difficulties managing this type of studies and adapt successfully to the labour market. Technical education is demanding, especially in the implementation of distance learning. In this article we are going to present the knowledge and experience gained during the pandemic of the new coronavirus SARS-CoV-2. The aim of this article is to evaluate the technical education implemented in the form of distance learning, to evaluate its positive and negative aspects based on the short research in the form of a questionnaire.
\end{abstract}

Key words: technical education, distance learning, teaching methods, modern concepts of teaching process, motivation of students, information and communication technologies

\section{Úvod}

S ohl'adom na skutočnost' prudkého rozvoja technických a informačno-komunikačných technológií v 21. storočí považujeme za dôležité rozvíjat’ osobnost’ žiaka v oblasti technického vzdelávania, a to i v prípade, ak je takéto vyučovanie realizované dištančnou formou. Problémy a prekážky v oblasti technického vzdelávania dištančnou formou je potrebné chápat' v širších súvislostiach, hl'adat' ich tak na strane žiakov, ako aj učitel'ov. Je potrebné definovat' indikátory problémov, príčiny stavu, faktory vyvolávajúce problémy a zamerat' pozornost' na včasnú intervenciu, a to na nižšom i vyššom sekundárnom stupni vzdelávania. Z uvedeného dôvodu je vel'mi dôležité poznat' súčasný stav technického vzdelávania $v$ kontexte dištančnej výučby. Prieskumom dištančného vzdelávania sa zaoberali aj učitelia v Pol'sku. Výsledky prieskumu odhalili mnoho problémov, ktorým učitelia 
čelili počas „dial'kového vzdelávania“. Zistilo sa, že v niektorých prípadoch: v domovoch žiakov bol nedostatok vybavenia informačnými technológiami, nedostatok komunikácie so žiakmi a ich rodičmi, nedostatok motivácie žiakov a u detí sa začali objavovat' zdravotné problémy. Učitelia si napriek tomu všimli niektoré pozitívne aspekty tejto formy vzdelávania, ktoré im umožnili viest' triedy počas pandémie. Bolo poznamenané, že vel’a učitel'ov naznačilo, že skúsenosti, ktoré získali v práci na dial'ku, poskytli dôležité indikácie pre d’alší rozvoj prístupov dištančného vzdelávania s malými det'mi, ktoré môžu pomôct' zmiernit' potenciálne sociálne nerovnosti, ktoré môžu vzniknút' v takejto krízovej situácii (Kruszewska, 2020). Našim úsilím a snahou je, aby učenie žiakov v technických predmetoch bolo maximálne efektívne, zlepšovala sa kvalita výchovnovzdelávacieho procesu, vzbudzoval sa záujem žiakov o technické vzdelávanie a nastal všestranný rozvoj osobnosti žiaka, a to aj počas dištančnej formy výučby, ktorá zaznamenala v dôsledku pandémie SARS-CoV-2 nevídaný rozmach.

\section{Výhody a nevýhody technického vzdelávania v kontexte dištančnej výučby}

V roku 2019 sa z Číny do celého sveta rozšírila pandémia nového koronavírusu SARS-CoV-2. Postihnutá bola celá spoločnost' vrátane Slovenska. Došlo k utlmeniu ekonomiky, zatváraniu prevádzok, služieb, inštitúcií, malých firiem i vel'kých spoločností, školstva nevynímajúc. Základné, stredné i vysoké školy boli nútené prejst’ na dištančnú formu vzdelávania. Učitelia nemohli vyučovat', žiaci i študenti sa nemohli učit' tak, ako boli zvyknutí. Dištančná forma vzdelávania sa stala dominantnou vo všetkých vyučovacích predmetoch. Slovenské školstvo nebolo na túto situáciu pripravené. Učenie online nie je presunutím herne alebo školskej lavice na internet. Vyžaduje si to úplne inú metodiku, plánovanie práce a d'alšie typy úloh a činností. Učitel' predovšetkým musí (mal by) prevziat' úlohu tútora vo vyučovacom procese (Nelson-Royes, 2015). Rýchly, neočakávaný a vynútený prechod z vyučovania na dial'ku priniesol množstvo výziev a obmedzení, ale aj príležitostí, ktoré je potrebné preskúmat' (Bozkurt, 2020). Vzniklo množstvo problémov, ktoré bolo potrebné ihned' riešit'. Problémy nesúviseli len s nepostačujúcim vybavením informačno-komunikačnými technológiami, či zlým prístupom na internet, ale i v nedostatočných skúsenostiach v práci s komunikačnými platformami. Avšak najväčším problémom, ktorý sa ukázal, bola skutočnost', že nie všetky vyučovacie predmety je možné odučit' dištančnou formou. Novej situácii sa muselo prispôsobit' aj technické vzdelávanie na základných a stredných školách. Učitelia základných a stredných škôl museli rozvinút' svoj tvorivý potenciál, ovel'a viac času venovat' motivácii žiakov, predovšetkým vnútornej. Bolo potrebné dištančnému vzdelávaniu prispôsobit' vhodné vyučovacie metódy i organizačné formy, upravit' učivo tak, aby bolo vhodné pre dištančné vzdelávanie. Ako problémové sa ukázali predmety, pri ktorých je ciel’om nadobúdat' a prípadne d'alej zdokonal'ovat' konkrétny druh činností, zručností i návykov, t. j. učebné predmety, pri ktorých majú psychomotorické ciele významné zastúpenie. Ak hovoríme o základných školách, máme na mysli predovšetkým predmety vzdelávacej oblasti Človek a svet práce, ako je technika, svet práce a vyučovacie predmety zamerané na informačno-komunikačné technológie a informatiku. V rámci stredných škôl sú to predovšetkým učebné odbory s odborným výcvikom, študijné odbory s odbornou praxou alebo s rozšíreným počtom hodín praktického vyučovania. Učebné plány obsahujú odborné predmety zamerané na robotiku, programovanie, technické kreslenie a iné, ktorých povaha a charakter učiva umožňujú realizovat' výučbu dištančne len čiastočne, prípadne to nie je vôbec možné. Príprava takejto hodiny pre dištančné vzdelávanie je náročná, učivo sa redukuje, prípadne upravuje len do teoretickej roviny, čo je pri takýchto predmetoch nežiadúce. Technické vzdelávanie realizované prezenčnou, ale i dištančnou formou na základných a stredných školách si kladie za ciel' rozvoj technického myslenia žiakov, ich kreativity, praktických zručností a napomáha tak $\mathrm{k}$ získavaniu technického rozhl'adu i kompetencií potrebných $\mathrm{v}$ správnom 
rozhodovaní sa pri výbere strednej školy, vysokej školy, či pri výbere svojho budúceho povolania. Dištančné vzdelávanie ako také má svoje výhody i nevýhody. Môžeme ich identifikovat' z hl'adiska pedagogického, psychologického, z pohl'adu učitel'ov i žiakov. Môžu pramenit' aj z charakteru a povahy učiva jednotlivých vyučovacích predmetov. Technické vzdelávanie nie je výnimkou. Ak by sme mali posúdit', či pri dištančnom vzdelávaní prevládajú pozitíva alebo negatíva, museli by sme brat' do úvahy viacero faktorov, ktoré vplývajú na výchovno-vzdelávací proces realizovaný práve touto organizačnou formou. Na základe vlastných skúseností v technickom vzdelávaní on-line i off-line dištančnou formou môžeme z pedagogického hl'adiska popísat' nasledujúce výhody:

- pri dištančnom vzdelávaní si môže žiak opakovane pozerat' študijné materiály, výučbové videá a zamerat' sa tak na časti, ktorým neporozumel,

- pri dištančnom vzdelávaní si žiak určuje svoje vlastné tempo vzdelávania,

- možnost' rýchlej spätnej väzby prostredníctvom textových správ, meetingov a konzultácií,

- materiál je rýchlejšie dostupný pre všetkých žiakov,

- možnost' komunikovat's učitel'om individuálne v intenzite podl'a potreby,

- štandardizované vedomosti - všetci žiaci dostanú rovnaké informácie,

- kvalitná podpora z hl'adiska IKT a softvéru,

- žiaci generácie „Z“ nemajú problém ovládat' vzdelávacie či komunikačné platformy,

- efektívne vzdelávanie z hl’adiska nákladov, šetrenie financií.

Uvedené výhody prezentovali žiaci, ktorých sme učili. Na túto problematiku vyjadrili svoj názor aj ich učitelia, ktorí uviedli nasledujúce výhody:

- výrazné zlepšenie zručností pri práci s informačno-komunikačnými technológiami,

- nové možnosti ako realizovat' výučbu,

- zlepšenie vzt'ahov medzi učitel'om a žiakom,

- dosahovanie lepších výsledkov u slabších žiakov,

- ak je výučba dobre pripravená z hl'adiska organizácie, je efektívna,

- možnost' využívat' aktivizujúce vyučovacie metódy,

- zlepšenie spolupráce s rodičmi.

Z psychologického hl'adiska uvádzajú učitelia tieto výhody:

- žiak si môže dobrovol'ne zvolit' čas a miesto, kde sa bude vzdelávat', napr. v pohodlí domova,

- kde môže trávit' viacej času v rodinnom kruhu,

- eliminácia stresu zo školského prostredia (napr. pri skúšaní).

Pri definovaní výhod je potrebné brat' do úvahy konkrétny vyučovací predmet, jeho učivo, vyučovacie ciele, didaktickú techniku a učebné pomôcky (bežne využívané pri prezenčnom vzdelávaní), ktoré nie je možné v rámci dištančného vzdelávania používat'. Nesmieme tiež zabúdat' na možnosti a schopnosti žiakov i učitel’ov. Na základe uvedeného i na základe vlastných skúseností musíme konštatovat', že pri technickom vzdelávaní dištančnou formou prevládajú negatíva nad pozitívami.

Z pohl'adu žiakov, ktorých sme učili uvádzame tieto nevýhody dištančného vzdelávania:

- jeden počítač (notebook) pri viacerých súrodencoch v rodine,

- zadávanie väčšieho počtu úloh a projektov ako počas prezenčnej formy vzdelávania,

- problémy so samoštúdiom (čítanie s porozumením) z učebných materiálov v elektronickej

- podobe, ktoré mali žiaci k dispozícii od vyučujúceho,

- závislost' na informačno-komunikačných technológiách,

- problémy s nestabilným internetovým pripojením,

- problém správne si organizovat' štúdium, efektívne využívat' čas,

- komplikovaná spolupráca so spolužiakmi napr. pri spoločnom riešení úloh.

Učitelia uviedli i tieto nevýhody dištančnej formy vzdelávania:

- absencia priameho kontaktu so žiakom a vzájomná interakcia, 
- časová náročnost’ tvorby kvalitných vzdelávacích materiálov vhodných na dištančnú výučbu,

- rozdielne technické a softvérové vybavenie počítačov vrátane podmienok internetového pripojenia,

- komplikované overovanie stupňa samostatnosti žiaka pri riešení projektov, testovaní,

- zložitejšia možnost' overenia, či žiak pochopil danú látku,

- pasívny a nezodpovedný prístup poniektorých žiakov k dištančnému vzdelávaniu,

- pri používaní niektorých technológií pre online komunikáciu sa museli učitelia zaškolit',

- pri niektorých odborných predmetoch, ako technické kreslenie, robotika, elektronika, odborný

- výcvik v dielňach, elektrotechnické cvičenia, fotografia museli učitelia prispôsobit' obsah

- vzdelávania dištančnej forme, prípadne ho redukovat'. Nie všetko učivo v týchto predmetoch bolo možné odučit' dištančnou formou. Dôvodom je chýbajúce technické a technologické vybavenie v domácich podmienkach vzdelávania i fyzická prítomnost' vyučujúceho, či majstra odbornej výchovy. Čast' učiva sa odučila v teoretickej rovine, čast' neodučeného učiva sa presúva na budúci školský rok. Ide predovšetkým o učivo, pri ktorom je potrebné si osvojit' konkrétne odborné zručnosti a návyky.

Z psychologického hl'adiska uvádzajú učitelia tieto nevýhody:

- absencia priameho kontaktu s rovesníkmi a s vyučujúcimi, odlúčenie od kolektívu,

- nepriaznivý vplyv na sociálne väzby v kolektíve,

- žiaci so ŠVVP majú problém pri dištančnej forme vzdelávania i kvôli absencii sociálneho kontaktu a problémami s individuálnym prístupom,

- potreba vysokej miery sebadisciplíny,

- dlhšia dištančná výučba má negatívny vplyv na vnútornú motiváciu a chut' niečo sa naučit',

- žiaci boli frustrovaní z toho, že nie všetko učivo, hlavne pri technických odborných predmetoch a odbornom výcviku je možné odučit’ plnohodnotne dištančnou formou. Obávajú sa, že im budú chýbat' potrebné odborné kompetencie a psychomotorické zručnosti, a že budú znevýhodnení pri uplatňovaní sa na trhu práce. Nie sú spokojní s tým, že sa čast' učiva presúva na d'alší školský rok. Dôjde tak k zhusteniu učiva.

Za nevýhodu dištančnej formy vzdelávania je považovaná i vysoká miera izolovanosti študujúceho. Izolovanost' môže byt' u niektorých študujúcich vel'kým problémom, k prekonaniu ktorého nestačí vysoká študijná motivácia. Intenzita sociálnych kontaktov je vel'mi dôležitý faktor práve pri vzdelávaní, pretože pozitívna sociálna klíma významne vplýva na študijné výsledky - hlavne u mladších l’udí (Trnková, 2003, zdroj: Gazdíkova, 2003). Dlhodobé dištančné vzdelávanie má ešte d’alšiu dôležitú nevýhodu. Nakol'ko sú žiaci doma v rodinnom prostredí a nechodia do školy, absentuje u nich každodenný „ranný rituál“ typický pri prezenčnom vzdelávaní: vstat', umyt' sa, obliect' sa, naraňajkovat' sa. Denne sa opakujúce činnosti vytvárajú u žiakov návyky dôležité pre ich budúci život, návyky k povinnosti ráno vstat' a íst' do školy, v budúcnosti do práce. Žial', pri úplnej absencii prezenčnej formy vzdelávania nie je možné tieto návyky plnohodnotne rozvíjat'. Nezanedbatel'ným faktom je aj to, že pri dištančnom vzdelávaní sa od všetkých detí automaticky vyžaduje, aby využívali také vlastnosti a zručnosti, ktoré sú u každého diet’at'a $\mathrm{v}$ inom štádiu rozvoja. Máme na mysli samostatnost', sebaovládanie, zodpovednost', vytrvalost', rýchlu adaptabilitu, psychickú odolnost' a iné. Ide o vel'mi dôležité silné stránky človeka. No nie sú prirodzené pre každé diet'a a ich rozvoj si vyžaduje systematické vedenie dospelého. Pritom každé diet’a žije v iných podmienkach (Ďuríková, 2021).

Krátkodobé dištančné vzdelávanie môže u žiakov rozvíjat' niektoré kompetencie dôležité pre ich osobný rozvoj a uplatnenie sa nielen v pracovnom živote. Máme predovšetkým na mysli rozvíjanie tak potrebných kl'účových kompetencií, ako informačno-komunikačné technológie, komunikatívne 
kompetencie, schopnost' učit' sa učit', prezenčné schopnosti a iné. Rozvíja sa samostatnost' a zodpovednost'. Ale nie je to tak u každého žiaka. Niektorým vyhovuje viac prezenčná forma vzdelávania. Z vlastnej pedagogickej praxe môžeme konštatovat', že žiaci, ktorí dosahovali výborné vyučovacie výsledky počas prezenčnej formy vzdelávania, zvládali i dištančnú formu vzdelávania bez problémov. Prospech u niektorých slabších žiakov sa pri dištančnej forme vzdelávania zlepšil.

\section{E-learning ako možnost' realizácie technického vzdelávania dištančnou formou}

Ak učitel' pravidelne sprostredkúva žiakom učivo, ktoré pre nich vopred pripraví, obmedzí sa na riešenie typických vzorových školských príkladov, žiaci sa po čase stávajú pasívnymi a vel'mi rýchlo si zvyknú na pohodlie, ktoré im učitel' svojím spôsobom práce častokrát nevedomky poskytuje. Činnost' žiakov je monotónna, reproduktívna, absentuje rozvoj vlastnej poznávacej a tvorivej činnosti, vytráca sa ,zvedavost““. Z vlastnej pedagogickej práce vieme, že ak žiaci narazia na prvý problém, ktorý majú vyriešit', ktorý sa vymyká z intervalu typicky školských úloh, zvyknú reagovat' slovami: „Nevieme to, toto sme sa neučili. Mohli by ste nám to ukázat?" Z uvedeného možno konštatovat', že žiaci by mali v škole viac samostatne pracovat', skúmat', byt' zvedaví a samostatne objavovat' nové poznatky. Do popredia sa dostávajú pojmy ako moderná škola, rozvoj tvorivého a kritického myslenia, kvalita vyučovacieho procesu, inovácie, aktivizujúce vyučovacie metódy a iné. Práve aktivizujúce vyučovacie metódy patria medzi súčasné, moderné koncepcie vyučovacieho procesu. Pri technickom vzdelávaní dištančnou formou využívali učitelia problémové a projektové vyučovanie, tiež aj kooperatívne vyučovanie, činnostné vyučovanie, ale i vyučovanie s využitím výpočtovej techniky, tzv. e-learning. Práve ten je považovaný za jeden z najmodernejších spôsobov vyučovania, pri ktorom sa využíva počítač s pripojením na internet. Turek (2014) konštatuje, že zatial' neexistuje jednotný názor, čo vlastne e-learning je. Popisuje, že jeden extrém predstavuje názory, že e-learning je akékol'vek vzdelávanie, pri ktorom sa používajú IKT a druhý extrém predstavujú názory, ktoré pod pojmom e-learning rozumejú iba vzdelávanie realizované prostredníctvom PC. Prikláňa sa však k názoru, že e-learning je vyučovanie a učenie prostredníctvom IKT (Turek, 2014).

Počas dištančného vzdelávania sa učitelia pravidelne, formou online meetingov zúčastňovali stretnutí predmetových komisií. Diskutovali o výučbe, možných problémoch, ktoré vznikali v priebehu vzdelávania a predkladali návrhy na ich odstraňovanie. Vyjadrovali sa i k používaným metódam a formám dištančnej výučby. $\mathrm{Na}$ základe záverov $\mathrm{z}$ diskusie učitel’ov môžeme konštatovat', že učitelia pri dištančnej výučbe technických predmetov využívali najčastejšie práve e-learning. Mali k dispozícii rôzne nástroje na jeho realizáciu, či už on-line alebo off-line. Vo väčšej miere sa však využíval s pripojením na internet. On-line formou mohli žiaci absolvovat' vyučovanie spoločne $\mathrm{v}$ reálnom čase, prípadne jednotlivo. $\mathrm{V}$ takomto prípade sa určil časový interval, resp. limit, v ktorom bolo možné vzdelávanie absolvovat'. Pri on-line e-learningu v reálnom čase (synchrónne), učitelia využívali Messenger, GoogleMeet, prípadne zdiel'ané výukové prostredie prostredníctvom webovej stránky. Výhodou pri tejto forme je, že sa najviac približuje prezenčnej forme v tom zmysle, že učitel' i žiaci môžu na seba bezprostredne reagovat'. Ak mal žiak nejaký problém, vedel učitel'ovi zadat' otázku a ten reagoval. V opačnom prípade, kedy sa žiaci vzdelávali tzv. nesynchrónne, využívali sa napr. cloudové úložiská, diskusné fóra a pod. Pri tejto forme je výhodou to, že žiak si sám mohol určit' tempo a čas, keby sa bude vzdelávaniu venovat'. Obidve on-line formy vzdelávania je možné kombinovat'. Nesmieme zabúdat' na technológie, bez ktorých by e-learning nemohol byt' realizovaný. Učitelia používali technológie v rámci on-line priestoru, ako napr. komunikácia v reálnom čase (Messenger, Viber, WhatsApp a i.) alebo rôzne cloudové riešenia, prostredníctvom ktorých zdiel'ali prakticky neobmedzené množstvo dokumentov rôzneho 
typu (textové, obrazové, zvukové a i.). Ďalej to boli moderné meetingové technológie, pomocou ktorých vedeli komunikovat' v reálnom čase obrazom, zvukom, alebo zdiel'aním (Zoom, GoogleMeet, Microsoft Teams a i.).

Tak ako všetko, aj e-learning má svoje výhody i nevýhody. Výhodami sú napr. zaujímavý spôsob vyučovania, ktorý môže pôsobit' na žiakov motivačne, jednotlivé kurzy môžu byt' „ušité“ na mieru pre konkrétnych používatel'ov - žiakov, všetky materiály sú v elektronickej podobe, eliminujú sa náklady v súvislosti s tlačou, prítomnost' určitého stupňa interaktivity umožňuje žiakovi určit' si samostatné tempo práce, prípadne poradie činností a i. Medzi hlavné nevýhody e-learningu radíme nutnost' ovládat' informačno-komunikačné technológie a tiež skutočnost', že nie každý obsah vzdelávania je najvhodnejšie odučit' prostredníctvom e-learningu. Patria tu aj zaobstarávacie náklady na IKT, prípadne softvér. Učitelia realizovali e-learning najčastejšie ako M-learning. Študijné materiály sprístupňovali žiakom prostredníctvom webových stránok alebo aplikácií.

Aby bol e-learning úspešný, dôležité sú nielen nástroje na jeho realizáciu, ale i vzdelávací obsah a štruktúra e-learningových kurzov. Učitelia i majstri odborného výcviku museli uplatnit’ svoj tvorivý potenciál, dištančnému vzdelávaniu prispôsobit' vhodné vyučovacie metódy i organizačné formy. Ovel'a viac času venovat' vnútornej motivácii žiakov, aktivovat' ich, vzbudit' zvedavost' a chut' i pri takejto forme vzdelávania sa niečo naučit'. Okrem uvedeného bolo potrebné prispôsobit' i učivo. Vzhl'adom na obsah technického vzdelávania, potrebné technické i technologické vybavenie, prevažne psychomotorické vyučovacie ciele boli tieto zmeny pre učitel'ov náročné. Učitelia sa snažili organizáciu technického vzdelávania realizovat' tak, aby i pri dištančnom vzdelávaní rozvíjali a podporovali užiakov tvorivé, kritické, hodnotiace i logické myslenie. Prispôsobenými aktivizujúcimi úlohami a projektami podnecovali u žiakov zvedavost', nadšenie, poznávanie a chut' objavovat' niečo nové. Materiálno-technické vybavenie školských dielní, odborných učební i laboratórií bolo zo dňa na deň nahradené výpočtovou technikou, internetom, videotutoriálmi či simulačným softvérom. Učitelia prezentovali nové poznatky v teoretickej rovine prostredníctvom online vyučovacích hodín, ktoré sa snažili spestrit’ rôznymi aktivizujúcimi úlohami a projektami. Vyučovanie bolo podporované názornými videoukážkami, počítačovými simuláciami rôznych technologických procesov, ktoré boli častokrát interaktívne. Žiaci mohli do nich zasahovat', menit' či prispôsobovat' tak prebiehajúce simulačné procesy, prípadne tvorit' nové. E-learning vyžívali i učitelia hotelových akadémií v študijných odboroch kuchár, cukrár a pekár. Dištančnou formou vedeli čiastočne realizovat' i praktické vzdelávanie. Žiaci pripravovali pokrmy doma v kuchyni. Učitel', resp. majster odbornej výchovy sledoval ich činnost' prostredníctvom online mítingu. Ďalšou možnost'ou bolo vyhotovenie video záznamu z konkrétnej praktickej činnosti žiaka, ktorý sa poslal vyučujúcemu na vyhodnotenie. Dištančne sa vyučovali aj technické odborné predmety zamerané na strojárstvo, stavebníctvo, ale i informačno-komunikačné technológie, robotiku, programovanie, počítačové siete, programovanie LEGO robotov a mnoho iných. Učitelia týchto predmetov vo vel'kej miere využívali online simulačné prostredia, aby aspoň čiastočne zabezpečili výučbu a žiaci mohli praktickou činnost'ou niečo tvorit'. Pri vyučovaní robotiky učitelia využívali rôzne platformy na inteligentné 3D simulácie robotov, aplikácie ako TinkerCAD, LOGO!Soft Comfort od spoločnosti SIEMENS a iné. Žiaci si mohli postavit' a naprogramovat' robota, prípadne nejaký proces, aktivitu alebo činnost'. Všetko však virtuálne v online prostredí. A to je práve vel'kým problémom technického vzdelávania. Psychomotorické vyučovacie ciele nie je možné plnohodnotne splnit' pri vyučovaní dištančnou formou. Už v spomínanom predmete robotika je súčast'ou učebných osnov aj výstavba robota zo stavebnice LEGO. Nie každý žiak má doma takúto stavebnicu, ktorá ani cenovo nie je vel'mi prístupná. Podobné problémy nastali i vo vzdelávaní zameranom na stavebníctvo či strojárstvo. Žiaci nemohli napríklad pracovat' s CNC 
strojom v školskej dielni, alebo pod vedením majstra postavit’ murovanú priečku. Túto situáciu vyriešili školy úpravou učebných osnov a takto zamerané učivo sa odučí po nástupe žiakov na prezenčnú formu vzdelávania, prípadne sa presunie na budúci školský rok.

\section{Hodnotenie dištančného vzdelávania z pohl'adu žiakov}

Na komplexné zhodnotenie dištančného vzdelávania (z viacerých aspektov) je potrebné realizovat' rozsiahlejší výskum. Prostredníctvom evaluačného dotazníka zameraného na dištančné vzdelávanie sme zist'ovali, ako študenti hodnotia on-line vyučovanie. Ciel'om bolo zistit' spätnú väzbu na realizované dištančné vzdelávanie. Dotazník bol anonymný a zúčastnilo sa ho 378 respondentov.

V prvej položke bola otázka zameraná na hodnotenie. Pýtali sme sa: Ako hodnotíš MNOŽSTVO úloh, ktoré ti učitelia posielajú na vypracovanie? Z grafu 1 je vidiet', že 47,5\% žiakov hodnotilo množstvo úloh, ktoré im učitelia posielali za primerané. 42,6\% si myslí, že ich je privel'a.

Graf 1 Množstvo úloh zasielaných učitel’mi počas dištančnej výučby.

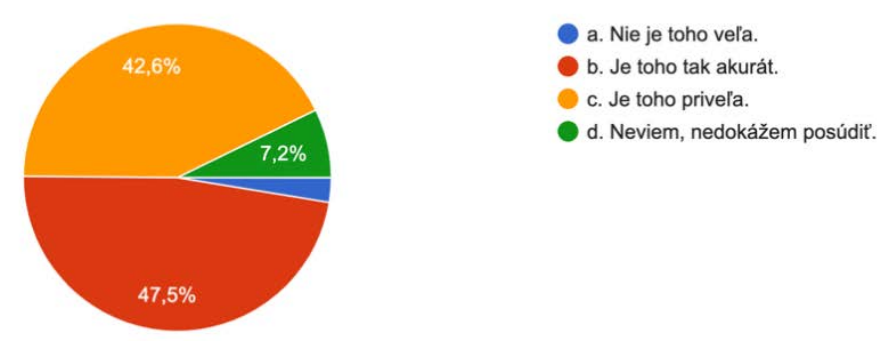

Graf č. 2 znázorňuje odpovede na otázku: Ako hodnotišs NÁROČNOSŤ úloh, ktoré ti učitelia posielajú na vypracovanie? Až 57,4\% žiakov si myslí, že úlohy sú skôr t’ažké.

Graf 2 Náročnost' úloh zasielaných učitel’mi na vypracovanie.
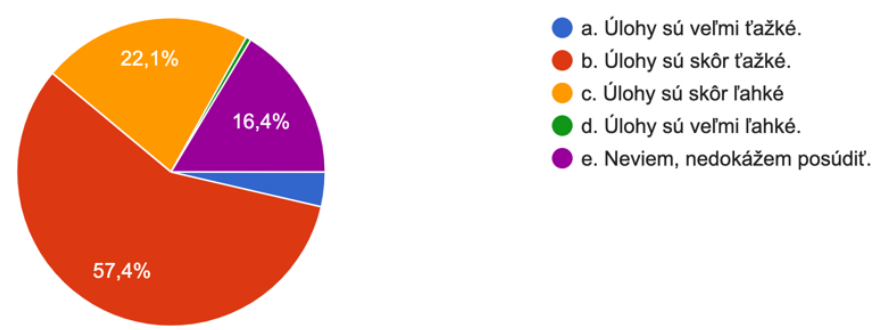

V štúdii prezentujeme len vybrané položky, podstatné a úzko súvisiace s ciel'mi predkladanej štúdie. V jednej položke sme sa pýtali: Kol’ko hodín denne sa v priemere učíš? Započitaj aj on-line vyučovanie. 34,4\% žiakov sa učilo od 3 do 5 hodín, 27,6\% od 5 do 7 hodín, 20,2\% 1 až 3 hodiny.

Ďalej žiaci odpovedali, ktorému nástroju pre komunikáciou s učitel’om dávajú prednost'. Microsoft Teams si vybralo 41,5\% žiakov. Druhá najpoužívanejšia bola komunikácia prostredníctvom SMS a telefónov. Túto možnost' využívalo 37,8\% žiakov. Nasledoval e-mail, Google Meet a WhatsApp. 
Graf 3 znázorňuje odpovede na otázku: Ako sa ti pracuje s nasledujúcimi nástrojmi pre on-line vyučovanie?

Graf 3 Práca s nástrojmi pre on-line vyučovanie.

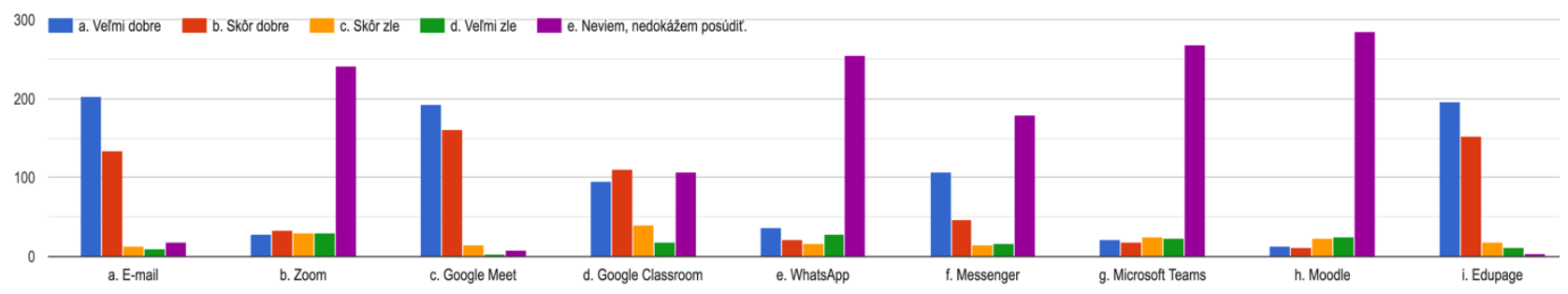

Ďalšou otázkou sme zist'ovali, čo si žiaci myslia o spravodlivosti hodnotenia úloh, ktoré dostávali od učitel'a. 53,1 \% žiakov považovali hodnotenie za skôr spravodlivé.

Graf 4 Spravodlivé hodnotenie úloh učitel'mi.

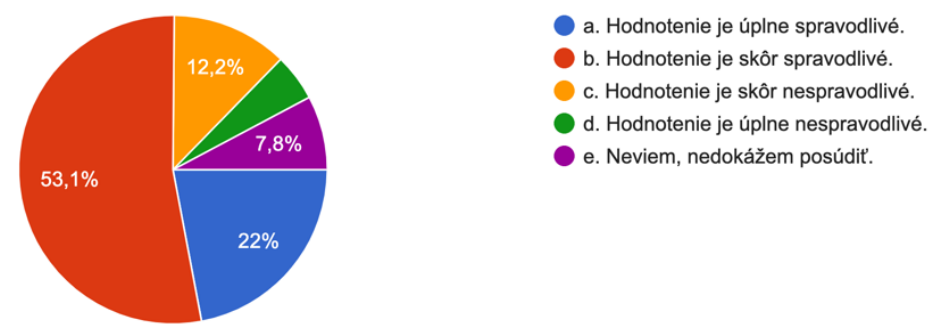

Žiaci odpovedali aj na otázku: Si schopný sa sám/sama naučit' látku z poslaných materiálov? Ako znázorňuje graf $5,40,6 \%$ žiakov odpovedalo, že zvládajú sa sami naučit' látku z poslaných materiálov, ale musia sa viac snažit'. Takmer $27 \%$ žiakom to samostatne vel'mi nejde, aj ked' sa snažia.

Graf 5 Schopnost’ naučit'sa samostatne látku z poslaných materiálov.
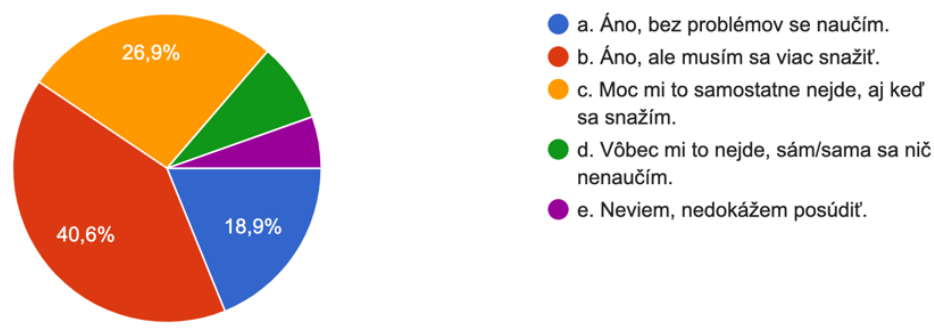

e. Neviem, nedokážem posúdit.

Pýtali sme sa žiakov, ako hodnotia komunikáciu so svojimi učitel’mi. Odpovede znázorňuje graf 6.

Ďalšou otázkou sme zist’ovali, či je pomer medzi samostatnými úlohami a spoločným on-line vyučovaním dostatočne vyvážený. Najviac, 49,1\% žiakom vyhovovalo, ako je vyučovanie nastavené. 
Graf 6 Hodnotenie komunikácie s vyučujúcimi.

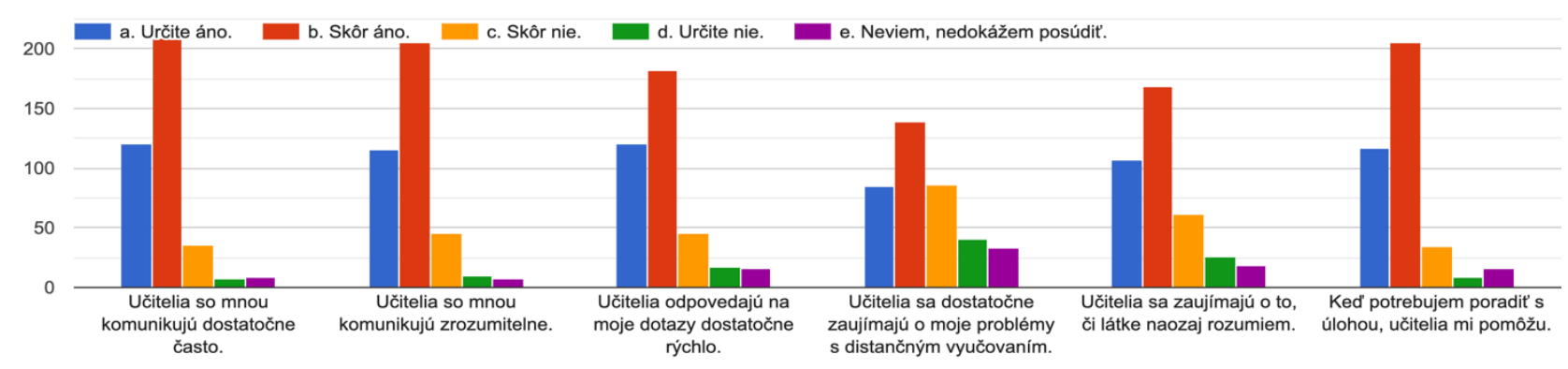

Graf 7 Hodnotenie pomeru medzi samostatnými úlohami a spoločným on-line vyučovaním.
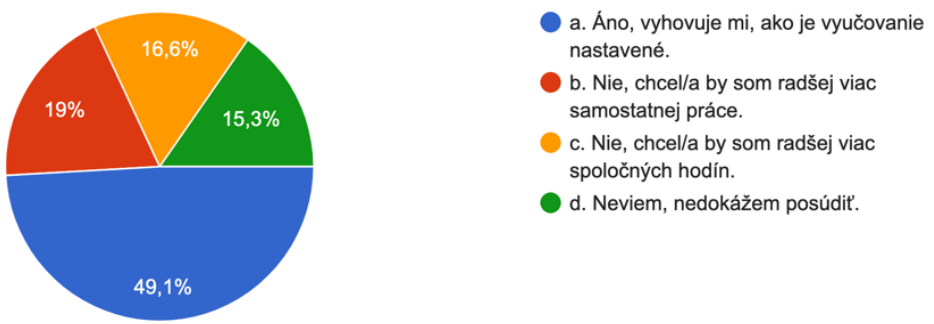

Podl’a žiakov sa dištančné vzdelávanie najlepšie realizovalo v odborných predmetoch, ako sú napr. programovanie, spracovanie sekvencií, elektronické publikovanie, grafický dizajn digitálnych médií, serverové technológie a skriptovacie jazyky. Naopak, podla žiakov sa dištančné vzdelávanie najhoršie realizovalo v predmete elektronika a prax.

Na otázku: „čo by podl’a teba mali učitelia na distančnom vyučovaní ZMENIŤ tak, aby ti viac vyhovovalo?"

Jeden respondent odpovedal: „Trochu viac pochopenia. Učitelia si neuvedomujú, že my študenti máme aj iné predmety. Z týchto predmetov dostávame domáce úlohy, pričom každá úloha má iný deadline a častokrát to sú náročné úlohy. Môže sa tak stat', že na jeden deň máme aj 4-5 úloh. To sa síce nemusí javit' ako vel'ké množstvo, ale pri jednej úlohe vieme strávit' aj 2 hodiny. Okrem toho chceme mat' aj nejaký vol'ný čas, nie sme predsa stroje. A najmä v tejto dobe, ked' neprichádzame do reálneho kontaktu s kamarátmi, nechodime von a podobne. Treba mysliet' aj na naše duševné zdravie".

Dotazníkovým prieskumom sme získali množstvo dát, ktoré nielen hodnotili spôsob výučby počas karantény, ale získali sme spätnú väzbu, ktorá pootvorila d’alšie otázky vhodné na skúmanie.

\section{Záver}

Ak je technické vzdelávanie realizované dištančnou formou, rozvoj technického, kritického, hodnotiaceho, ale i divergentného je výrazne st'ažené. Absentuje tu sociálny kontakt. Úspešnost' využitia vyučovacích metód závisí od mnohých faktorov, ako materiálno-technických podmienok dištančnej výučby, komunikačnej platformy, odučeného učiva, organizácie vyučovacej jednotky, psychickej úrovne žiakov, ale i pedagogického majstrovstva učitel'a. Mnohé témy bolo možné odučit' len v teoretickej rovine. Psychomotorické vyučovacie ciele nebolo možné plnohodnotne splnit' pri vyučovaní dištančnou formou. Na základe realizovaného prieskumu sme zistili, že 
technické vzdelávanie realizované dištančnou výučbou žiaci hodnotili skôr kladne. Musíme ale konštatovat', že technické vzdelávanie nie je možné plnohodnotne odučit’ takouto formou.

Príspevok vznikol v rámci grantovej úlohy VEGA č. 1/0383/19 Analýza stavu v technickom vzdelávaní a rozvoj technických zručností žiakov na primárnom stupni školy, ktorého zodpovedná riešitel'ka je doc. PaedDr. Zlatica Hul'ová, PhD., (2019 - 2021).

\section{Literatúra}

Bozkurt, A. \& Sharma, R. C. (2020). Emergency Remote Teaching in a Time of Global Crisis Due to CoronaVirus Pandemic. In Asian Journal of Distance Education 15 (1): i-vi. Accessed 24 July 2020. Dostupné na: https://scholar.google.com/scholar_lookup?hl=en\& volume $=15 \&$ publication_year=2020\&pages $=\mathrm{i}$-vi\&issue=1\&author=A.+Bozkurt\&author= R.+C. + Sharma\&title=Emergency + Remote + Teaching + in $+a+$ Time + of + Global + Crisis + Due + to + Cor onaVirus+Pandemic.

Ďuríková, K. (2021). Školská psychologička: Diet’a potrebuje priamy kontakt s učitelom a kamarátmi. In https://uzitocna.pravda.sk/ [Online]. [Cit. 2021-04-28]. Dostupné na: https://uzitocna.pravda.sk/skola/clanok/564089-skolska-psychologicka-z-dlhodobeho-hladiskapotrebuje-dieta-priamy-kontakt-s-ucitelom-a-kamaratmi/. Gazdíková, V. (2003). Základy dištančného elektronického vzdelávania. Trnava: PgF TU. Kruszewka, A., Nazaruk, S. \& Szewczyk, K. (2020). Polish teachers of early education in the face of distance learning during the COVID-19 pandemic - the difficulties experienced and suggestions for the future, Education 3-13, DOI: 10.1080/03004279 .2020.1849346.

Nelson-Royes, A. M. (2015). Why Tutoring? A Way to Achieve Success in School. Lanham: Rowman \& Littlefield Publishing Group. Dostupné na: https://books.google.sk/books?hl=en\&lr=\&id=SzXHBwAAQBAJ\&oi=fnd\&pg=PR5\&ots=ufjx1VA VJj\&sig=t6Hn3sdPxNKlj9wprpNtuVgGkOA\&redir_esc=y\#v=onepage\&q\&f=false.

Turek, I. (2014). Didaktika. Bratislava: Wolters Kluwer

\section{Kontaktná adresa:}

Zlatica Hul'ová, doc. PaedDr. PhD.

Katedra predškolskej a elementárnej pedagogiky, Pedagogická fakulta KU, Hrabovská cesta 1, 03401 Ružomberok, tel.: +421 905609 549, e-mail: zlatica.hulova@ku.sk

Peter Tokoš, Ing.

Katedra didaktiky odborných predmetov, VŠ DTI, Sládkovičova 533/20, 01841 Dubnica nad Váhom, tel.:+421 904120 624, e-mail: peter.tokos@petertokos.com 